\title{
Effects of climate change on killing frost in the Canadian prairies
}

\author{
Yong $\mathrm{He}^{1,2}$, Hong Wang ${ }^{1, *}$, Budong Qian ${ }^{3}$, Brian McConkey ${ }^{1}$, Herb Cutforth ${ }^{1}$, \\ Reynald Lemke ${ }^{4}$, Ron DePauw ${ }^{1}$, Kelsey Brandt ${ }^{1}$, Tom McCaig ${ }^{1}$, Kelin Hu ${ }^{2}$, \\ Gerrit Hoogenboom ${ }^{5}$
}

${ }^{1}$ Semiarid Prairie Agricultural Research Centre, Agriculture and Agri-Food Canada, Box 1030, Swift Current, Saskatchewan S9H 3X2, Canada

${ }^{2}$ Department of Soil and Water Sciences, Resources and Environmental Sciences College, China Agricultural University, Beijing 100094, China

${ }^{3}$ Eastern Cereal and Oilseed Research Centre, Agriculture and Agri-Food Canada, Ottawa, Ontario K1A 0C6, Canada

${ }^{4}$ Saskatoon Research Centre, Agriculture and Agri-Food Canada, Saskatoon, Saskatchewan S7N 5A8, Canada

${ }^{5}$ AgWeatherNet, Washington State University, Prosser, Washington 99350, USA

\begin{abstract}
Killing frost is a significant factor that governs agricultural production on the Canadian prairies across Alberta, Saskatchewan and Manitoba. The objective of this study was to assess the potential changes in the spatial distribution of killing frosts for spring wheat Triticum aestivum L. on the Canadian prairies under projected future climates. To accomplish this, (1) daily climate data (from 1961-1990) at 60 weather stations across the agricultural regions of the Canadian prairies were obtained ${ }_{i}(2) 3$ climate scenarios were developed for the period 2040-2069; (3) killing frost indices for spring wheat were calculated for both the baseline and the 3 climate change scenarios for all weather stations, and (4) geostatistical methods were used to interpolate the indices from the stations to fine grids covering the whole agricultural regions on the Canadian prairies. Results show that under baseline conditions - with the exception of some pockets in all 3 provinces - areas with the earliest mean dates of last spring killing frost (LSKF) (April 12 to April 14) are located in Alberta and west-central Saskatchewan; while the earliest mean first fall killing frost (FFKF) (September 16 to September 20) occurs mainly in southwest Saskatchewan. The 3 climate change scenarios projected an earlier LSKF (April 6 or earlier compared to April 14) and a later FFKF (October 3 or later compared to September 27). As a result, there was a longer killing frost free period (KFFP), which increased under all scenarios by $\geq 14 \mathrm{~d}$ compared to the baseline climate. Although the changes differed among the climate change scenarios, the major characteristics were fairly consistent. The results from this study will help formulate strategies to address climate change across the Canadian prairies, such as seeding earlier and choosing cultivars with later maturity dates and longer growing periods.
\end{abstract}

KEY WORDS: Killing frost $\cdot$ Climate change $\cdot$ Spatial distribution

\section{INTRODUCTION}

The Canadian prairies (Alberta, Saskatchewan and Manitoba) are a major exporter of cereals and thus an important supplier of food for the global community (Parry 1990).
In the summer, continental air masses are dominant. Rainfall generally decreases from east to west. In the winter, cold arctic air masses are common. These weather phenomena produce a large annual temperature range with short hot summers and cold winters (Nadler 2007). Such harsh conditions create a 
unique set of challenges for agriculture, and make it sensitive to climate change and climate variability (Conly \& van der Kamp 2001).

A killing frost is one of the most devastating weather events that can affect agricultural productivity on the Canadian prairies. An untimely killing frost event can result in substantial losses in crop yield and quality (Preston et al. 1991). To achieve maximum yield, growers must seed so that the crop is not at a sensitive stage when frost is most likely to occur. Knowledge of the spatial distribution and length of the killing frost free period (KFFP) can be the first step in assessing the suitability of crops for a region.

The spatial distribution of frost events on the Canadian prairies has been studied based on historical weather data (Longley 1967, Cutforth et al. 2004, Nadler 2007) and for future climate change scenarios (McGinn et al. 1999). These studies provide useful information for agricultural practices at a regional scale, but improvements are needed. Firstly, lethal temperatures for $50 \%$ plant kill (LT50) should be used for LSKF and FFKF, rather than $0^{\circ} \mathrm{C}$ or other temperatures higher than LT50. Using high critical temperatures will result in an underestimation of optimum seeding window for Canadian Prairie producers. Secondly, killing frost events should not be directly deduced from climate change scenarios and subsequently used to represent a large grid area, because climate scenarios derived from General Circulation Models (GCMs) at a weather station site can only represent a limited area; therefore this kind of scale-up may be inappropriate (Barrow \& Hulme 1996). Deriving killing frost events from localized climate scenarios to obtain their spatial distribution by spatial interpolation may be a better option.

The goal of this study was therefore to (1) investigate the killing frost related indices as they apply to the thermal conditions encountered within the Canadian prairies using baseline weather data, (2) analyze the killing frost indices under projected future climate conditions, and (3) interpolate the point results from (1) and (2) to show results for all agricultural land on the Canadian prairies using geostatistical methods.

\section{MATERIALS AND METHODS}

\subsection{Study area}

The Canadian prairies are situated at the northern fringes of the agricultural production zone within the Great Plains of North America (Nadler 2007). In this study, crop districts from the provinces that encompass the Canadian prairies (Alberta Saskatchewan and Manitoba) were selected (Fig. 1). These crop districts are defined by the agricultural agencies in each province and are used for mapping and spatial analysis for agricultural information. The prairies cover an area of $520000 \mathrm{~km}^{2}$ and extend northward from latitude $49^{\circ}$ to $54^{\circ} \mathrm{N}$ and westward from longitude $96^{\circ}$ to $114^{\circ} \mathrm{W}$ (Raddatz 1998). There are 3 distinct agroclimatic zones in this area: sub-humid, semi-arid and arid (Mkhabela et al. 2011). Annual precipitation in the Canadian prairies ranges from 300 to $550 \mathrm{~mm}$ and increases mainly in a southwest to northeast direction (Herrington et al. 1997). Approximately two-thirds of the total annual precipitation is received during the summer months (May to August) and the period of continuous snow cover typically lasts 4 to 5 mo (Cohen et al. 1992, Quiring \& Papakryiakou 2003).

\subsection{Historic weather data}

Daily weather data including maximum and minimum temperatures and precipitation for 60 stations on the Canadian prairies (Fig. 1) between 1961 and

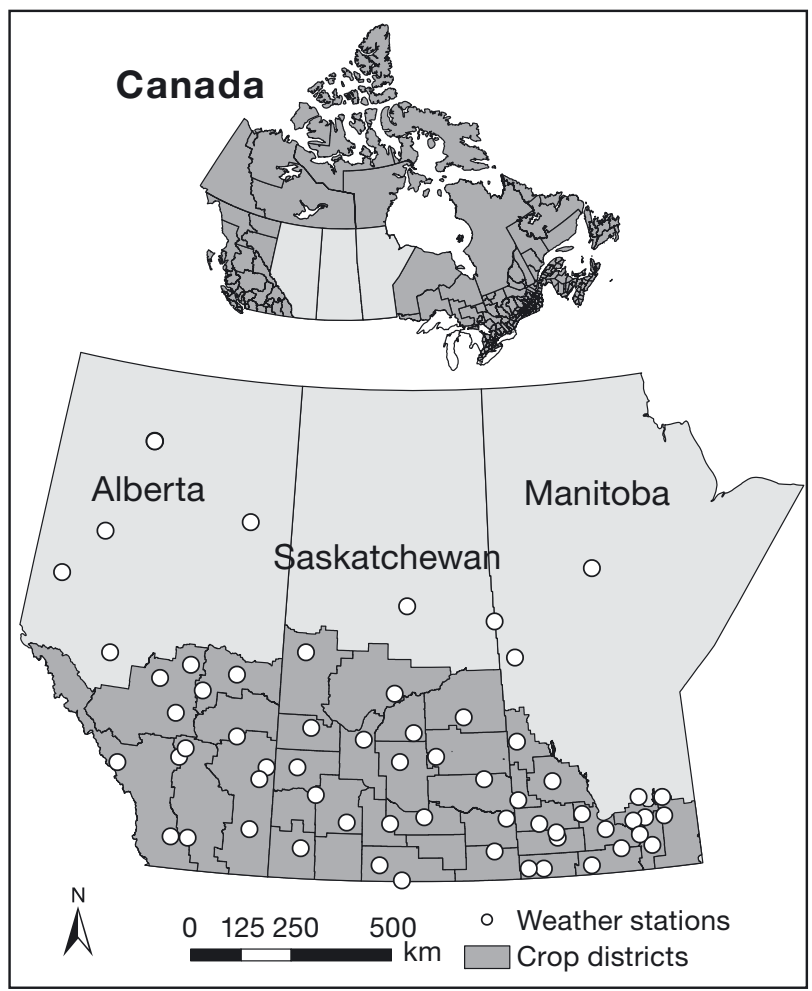

Fig. 1. The Canadian prairies: extent of agricultural regions in Alberta, Saskatchewan and Manitoba and (O) weather stations that provided data for this study 
1990 were obtained from Environment Canada (1993). This $30 \mathrm{yr}$ period was selected to represent the current climate because, in most cases, it has the most complete data (Alexandrov \& Hoogenboom 2000). This historic weather data was then used to generate a baseline climate and 3 projected future climate change scenarios.

Note that the baseline climate for the period 19611990 is significantly different from the climate in recent years, for example 1981-2010. A recent study (Qian et al. 2012) showed significant changes in agroclimatic conditions observed in Canada between different $30 \mathrm{yr}$ periods. However, the 1961-1990 period has been and continues to be used as the standard reference (baseline) in many studies of climate change (Canadian Climate Change Scenarios Network 2011).

\subsection{Baseline climate and climate change scenarios}

A baseline (1961-1990) and 3 projected future climate change scenarios in the 2050s (2040-2069) for each station were generated using the stochastic weather generator AAFC-WG by perturbing weather generator parameters (Qian et al. 2005, 2010a, $2010 \mathrm{~b})$ based on climate change simulations conducted by the third generation Canadian global climate model (CGCM3) (Kim et al. 2002, 2003). The latter simulations were generated using 3 greenhouse gas (GHG) emissions forcing scenarios - IPCC Special Report on Emissions Scenarios (SRES) scenarios $\mathrm{A} 2, \mathrm{~A} 1 \mathrm{~B}$ and $\mathrm{B} 1$ - which represent the range of emissions trajectories projected to the end of this century (IPCC 2000). Qian et al. (2011) compared extremes between observed weather and synthetic data. They found that AAFC-WG is capable of reproducing a realistic representation of extreme temperature events. Therefore, we used synthetic baseline data to ensure that comparison with the synthetic future climate data was consistent.

Synthetic 3000 yr weather data were generated by AAFC-WG for the baseline period and for each scenario. Long synthetic data series can provide accurate estimates of statistical properties, ensuring that any significant difference between the observed series and the synthetic series is not a result of sampling error, as the observed series is only a short part of the 'real' stochastic process (Qian et al. 2004). Qian et al. (2004) assessed the capability of AAFC-WG to reproduce probability distributions, means and variances of observed daily precipitation, and maximum and minimum temperature for diverse Canadian cli- mates. They found that AAFC-WG performed very well in simulating temperature-related statistics, including agroclimatic indices for frost and killing frost events.

\subsection{Crop and killing frost related indices}

Spring wheat Triticum aestivum L. was selected as the reference crop because it is grown in all crop districts and occupies a large amount of the land base in this study area (Statistics Canada 2011). Killing frost (lethally low temperature) and their occurrence at different times within any given year have serious effects on agricultural production. There are 2 conditions of killing frost of particular importance in ascertaining the time available for crop growth. The last spring killing frost (LSKF) can dictate seeding dates whereas the first fall killing frost (FFKF) determines the last day on which growth can take place. The killing frost is highly variable and the extent of damage depends upon the types of frost and stage of crop growth which is affected. Shroyer et al. (1995) detailed the tolerance of wheat response to killing frost for different growth stages. Whaley et al. (2004) concluded that susceptibility increases with increasing development of the crop. In this study, we focused on the occurrence of killing frost at early and late stages of wheat growth.

For LSKF, many studies found that the LT50 in the early growth stage of acclimated wheats including Canadian spring cultivars is $-8^{\circ} \mathrm{C}$ (Macdowall 1974, Charron et al. 2002, Gulick et al. 2005, Ganeshan et al. 2008). Slight vegetative damage may occur at these temperatures, but wheat plants can easily recover from this since the growing point is at or below the soil surface and is well buffered against fluctuating air temperatures. In a long-term study at Swift Current, Saskatchewan, historical records showed that spring wheat seedlings experienced a temperature of $-7.3^{\circ} \mathrm{C} 1$ to $2 \mathrm{wk}$ after germination in both 1953 and 1960 without any damage (B. Zentner, pers. comm.). However, the temperature of LSKF may be higher or even lower depending on the hardening process. In the case of hardening, the prior sequence of temperature events is important when determining the killing frost temperature, a complicated process beyond the scope of this paper. We used a seeding date model (McGinn et al. 1999) and a modified growth model-the Decision Support System for Agrotechnology Transfer (DSSAT) Crop Systems Model v4.0) (Jones et al. 2003, Wang et al. 2009) — to simulate dates of seeding and emer- 
gence, and killing temperatures. Predicted killing temperatures were always at or below $-8^{\circ} \mathrm{C}$ across years and regions, indicating that the environment on the Canadian prairies can harden spring wheat to tolerate air temperature as low as $-8^{\circ} \mathrm{C}$. Therefore, a minimum daily air temperature of $-8^{\circ} \mathrm{C}$ was selected as the value for LSKF in this study. Other compounding variables such as soil moisture, snow cover and surface crop residue conditions that may exacerbate or mitigate the freezing effect were not considered.

For FFKF, Reinheimer (2010) found that LT50 for reproductive organs is between -4 and $-6^{\circ} \mathrm{C}$ for Australian spring wheat. Fuller et al. (2007) indicated that wheat has an inherent frost resistance to $-5^{\circ} \mathrm{C}$ and should be able to escape frost damage at ear emergence if the temperature does not drop below this point. Frosts below this temperature however have a high chance of causing substantial damage, and exposure to acclimation temperatures appears to be ineffective in improving resistance even in a hardy cultivar. However, for FFKF we should consider the impact of frost not only on the grain yield, but also on grain quality (Dexter et al. 1985). Preston et al. (1991) indicated that the response of quality characteristics to frost is dependent on both temperature and maturity. At early maturity, temperatures below $-3^{\circ} \mathrm{C}$ resulted in decreased kernel weight and protein content for a Canadian hard red spring wheat, Neepawa. Effects were less evident at later maturity. We decided to choose a relatively conservative temperature of $-2.2^{\circ} \mathrm{C}$ for FFKF based on previous studies (Macdowall 1974, Single \& Marcellos, 1974, Hayter 1992, Sharratt et al. 2003).

\subsection{Geostatistical methods}

Geostatistical methods are used to scale up from station data to an entire region for a spatial assessment. One of the benefits of applying geostatistics is that spatial patterns can be detected, estimated and mapped. The geostatistical methods that have been applied to other fields of study can also be used in the spatial assessment of agro-climate indices (Alexandrov \& Hoogenboom 2000, Quiring \& Papakryiakou 2003, Geerts et al. 2006). In this study, the spatial assessment of killing frost was conducted by using geostatistical methods performed in ArcGIS 9.2 platforms.

The main principles and theoretical details of geostatistics have been described in the literature
(Goovaerts 1997, 1999) so it is not necessary to explain them in detail here. There are 3 steps involved: (1) exploratory data analysis, (2) geostatistical analysis, and (3) estimation of parameter values for unsampled positions (Isaaks \& Srivastava 1989). Geostatistical analysis in turn comprises 2 steps: (1) the calculation of an experimental variogram and (2) the fitting of a variogram model to the experimental variogram. Because the experimental variogram is an empirical estimate of the covariance of a Gaussian process, it may not be positive definite, and hence not directly usable in interpolation, without constraints or further processing. Therefore, the variogram models are used most commonly (i.e. the Linear, the Spherical and the Gaussian models) to guarantee the variogram is positive (Deutsch \& Journel 1992). The fitted variogram model is then used in various interpolation methods. Kriging is one of the more flexible interpolation methods, which has been proven useful and is popular in many fields (Holdaway 1996, Alexandrov \& Hoogenboom 2000). In this study, ordinary kriging was used to estimate the values of the points at the specified grid nodes, using the geographic coordinates of every weather station.

Because each spatial interpolation technique has its errors, conclusions have to be drawn and used with caution when proceeding to decision making on the basis of estimated results. In order to yield a sound estimation for each agroclimatic index, crossvalidation should be used to evaluate the prediction of the final ordinary kriging (Isaaks \& Srivastava 1989). In this study, we used root mean square error (RMSE) and root mean squared standardized error (RMSSE) to evaluate the performance of the variogram model and the final ordinary kriging. In general, the better the estimated results, the smaller the RMSE. In addition, the RMSSE should be close to 1 if the predicted standard errors are valid. Values of RMSSE that are $>1(<1)$ indicate that the ordinary kriging prediction is underestimated (overestimated) (Johnston et al. 2001).

\subsection{Data analysis}

Statistical analyses were done using SAS (SAS Institute 1999). Means and standard deviations of synthetic (baseline and climate change scenarios) air temperature were calculated by PROC MEANS software. PROC UNIVARIATE software was used to examine normality (the Shapiro-Wilk test was used) of the data used for geostatistics. 


\section{RESULTS AND DISCUSSION}

\subsection{Exploratory data analysis}

The average changes in maximum, minimum and mean temperatures between baseline (1961-1990) and projected (2040-2069) climates of 51 weather stations as predicted by the 3 climate scenarios for agricultural regions on the Canadian prairies are shown in Table 1. Nine of 60 weather stations were removed in this analysis because they are outside the crop districts. However, those 9 weather stations were used in the following mapping since they can provide useful information for spatial estimation. The descriptive statistics for killing frost indices under the baseline climate are presented in Table 2 . The average and maximum (i.e. latest) LSKF in 1961-1990 were April 15 and 28, respectively. The average and minimum (i.e. earliest) FFKF in 1961-1990 were September 27 and August 29 respectively. The average KFFP was 163.8 d. LSKF occurred most frequently between April 14 and April 18 in the baseline climate (Fig. 2). Under projected future climates, dominant dates of LSKF advanced (i.e. occurred earlier) (Fig. 3). For example, the dominant date of LSKF was April 5 for scenarios A2 and B1 and April 6 for scenario A1B. FFKF was delayed (i.e. occurred later) under the climate change scenarios compared to the baseline climate. The delay was greatest in Scenario A2, when

Table 1. Average changes in maximum, minimum and mean temperatures between baseline (1961-1990) and future (2040-2069) climates at 51 weather stations in agricultural regions of the Canadian prairies, as predicted based on the IPCC's climate change scenarios A2, A1B and B

\begin{tabular}{|lccc|}
\hline Climate scenario & $\mathrm{T}_{\text {Max }}\left({ }^{\circ} \mathrm{C}\right)$ & $\mathrm{T}_{\text {Min }}\left({ }^{\circ} \mathrm{C}\right)$ & $\mathrm{T}_{\text {Mean }}\left({ }^{\circ} \mathrm{C}\right)$ \\
\hline A1B & 2.88 & 2.94 & 2.91 \\
A2 & 3.03 & 3.53 & 3.28 \\
B1 & 2.25 & 2.53 & 2.39 \\
\hline
\end{tabular}

Table 2. Descriptive statistics of killing frost indices (51 stations $\times 3000 \mathrm{yr}$ ) within crop districts for baseline climate. The synthetic 3000 years represent the period 1961-1990. LSKF: last spring killing frost; FFKF: first fall killing frost; KFFP: killing free frost period; SD: standard deviation; *Significant (Shapiro-Wilk normality test performed at the 0.05 significance level)

\begin{tabular}{|lcccc|}
\hline & Minimum & Mean & Maximum & SD (d) \\
\hline LSKF & April 4 & April 15* & April 28 & 4.7 \\
FFKF & August 29 & September 27* & October 18 & 9.0 \\
KFFP (d) & 122.8 & $163.8^{*}$ & 192.4 & 12.8 \\
\hline
\end{tabular}

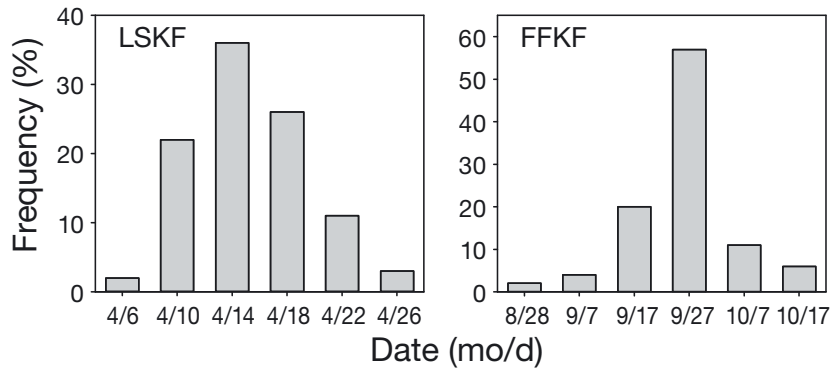

Fig. 2. Last spring killing frost (LSKF) and first fall killing frost (FFKF) under baseline climate for all stations (51) and all years (3000). See Table 2 for abbreviations

the dominant date of FFKF was October 15, compared to September 27 in the baseline climate.

Increased temperatures advanced LSKF and delayed FFKF under all scenarios (Table 3). The advance of LSKF was greater under scenario A2 ( 14 d) than under scenarios B1 ( 9 d) and A1B ( 8 d). Scenario A2 also showed the greatest delay in FFKF $(\sim 16 \mathrm{~d})$, followed by scenarios B1 ( 12 d) and A1B ( 10 d). Therefore, scenario A2 had the longest KFFP. The standard deviations were similar for LSKF, FFKF, and $\operatorname{KFFP}(\sim 2 \mathrm{~d})$.

The percentage of LSKF (FFKF) that occurs after (before) the average LSKF (FFKF) is shown in Table 4. This information, along with the frequency distributions (Figs. 2 \& 3) can be used for simple risk analysis by decision makers.

\subsection{Geostatistical analysis}

Anisotropic experimental variograms were calculated for the frost indices. However, the variograms exhibited a pure nugget effect in most directions (data not shown), which may have been due to scarcity of data (Esbensen et al. 2007). Using an anisotropic variogram model in such a case is improper. For each of the indices, we only used one selected direction that was suitable for variogram modeling (Fig. 4). The variogram models are constructed from the experimental variograms on the basis of experience and with the help of error analysis (Isaaks \& Srivastava 1989, Woodcock et al. 1988). The parameters for the variogram models are presented in Table 5.

\subsection{Mapping}

Regional mapping of the killing frost related indices was conducted at a spatial scale of $2.5 \times 2.5 \mathrm{~km}$ for agricultural regions on the Canadian prairies and 

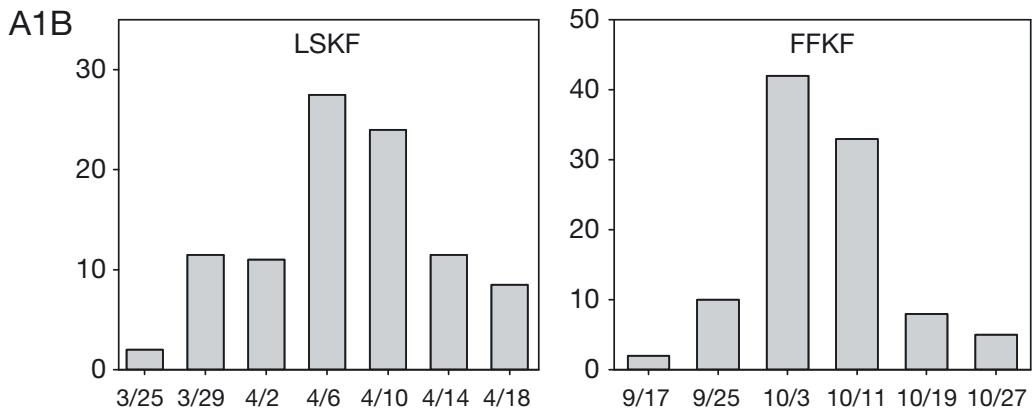

this in mind, most of the mapping results of this study have acceptable estimation error (i.e. RMSE $<10$ d). However, compared to other indices, the estimation of KFFP under baseline conditions has a relatively high RMSE and the estimation of change of KFFP for scenario A2 has higher deviation of RMSSE from the expected value of 1.
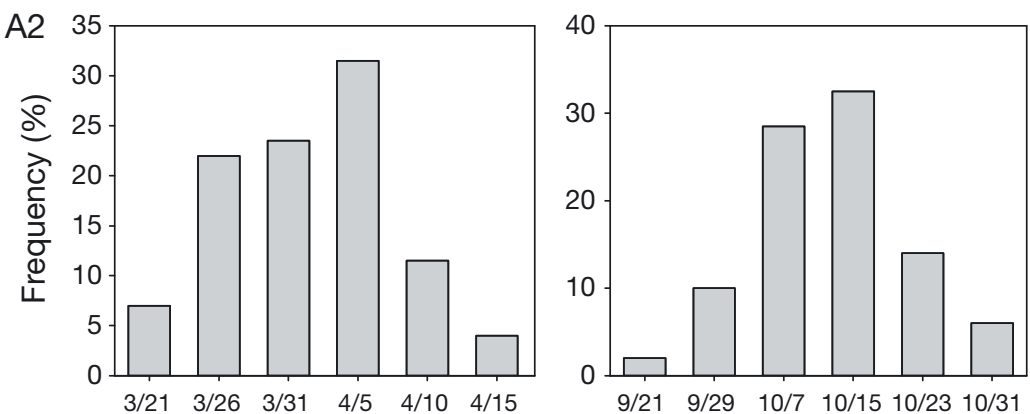

\subsubsection{Baseline climate (1961-1990)}

Fig. 5 shows the distribution of index values under the baseline climate that was estimated using ordinary kriging. With the exception of some pockets in all 3 provinces, areas in Alberta and central west Saskatchewan have the earliest mean LSKF (April 12 to April 14). In Saskatchewan, the southwest and northeast corners have the latest mean LSKF (April 21 to April 27). In Manitoba, the earliest average LSKF occurs in the central south part of the province. The latest mean FFKF occurs most consistently in southern Manitoba, similar to results reported by Nadler (2007). Earliest mean FFKF occurs principally in southwestern Saskatchewan (September 16 to September 20). In Alberta, FFKF mainly occurs around September 24 or September 25. There is an increasing delay in FFKF moving from southwestern Saskatchewan northeastwards to Manitoba. Areas with the longest KFFP (170 to $186 \mathrm{~d}$ ) are located primarily in central south Manitoba and a small area in northern Alberta. For most areas between eastern was accompanied by error estimation (Table 6). These errors indicate which indices require additional data collection in order to increase overall reliability. Hijmans et al. (2003) pointed out that researchers will have to strike a balance between ideal procedures and availability of data and models. With Alberta to parts of Manitoba, KFFP ranged from 154 to $163 \mathrm{~d}$ with the exception of the central part of Saskatchewan (164 to 169 d).

According to historical observation on the Canadian prairies, the seeding dates of spring wheat range from April 20 to June 8 (Bootsma \& De Jong

Table 3. Changes in killing frost indices (d) under climate change scenarios A1B, A2 and B1 for all stations (51) and all years (3000). LSKF and FFKF: last spring and first fall killing frost, respectively; KFFP: killing frost free period. ${ }^{*} \mathrm{p}>0.05$ for Shapiro-Wilk normality test performed at the 0.05 significance level

\begin{tabular}{|c|c|c|c|c|c|c|c|c|c|}
\hline & \multicolumn{3}{|c|}{ Minimum } & \multicolumn{3}{|c|}{ Mean (SD) } & \multicolumn{3}{|c|}{ Maximum } \\
\hline & A1B & A2 & B1 & $\mathrm{A} 1 \mathrm{~B}$ & $\mathrm{~A} 2$ & B1 & A1B & A2 & B1 \\
\hline Advance of LSKF & 4.0 & 8.3 & 3.7 & $8.4(1.7)^{*}$ & $13.8(2.3)^{*}$ & $9.0(2.2)^{*}$ & 12.7 & 19.8 & 12.9 \\
\hline Delay in FFKF & 6.0 & 13.0 & 10.0 & $10.2(2.4)^{*}$ & $16.2(2.1)^{*}$ & $12.4(1.8)^{*}$ & 20.7 & 20.0 & 20.2 \\
\hline Increase in KFFP & 14.0 & 25.8 & 16.7 & $18.7(2.4)^{*}$ & $30.0(2.1)^{*}$ & $21.4(2.3)^{*}$ & 30.0 & 35.7 & 28.5 \\
\hline
\end{tabular}


Table 4. Percent (mean \pm SD) of LSKF (FFKF) that occurs after (before) the average LSKF (FFKF) for all 51 stations and all 3000 years, under baseline conditions and alternative climate change scenarios. LSKF and FFKF: last spring and first fall killing frost, respectively

\begin{tabular}{|lcc|}
\hline & LSKF & FFKF \\
\hline Baseline & $48.8 \pm 1.97$ & $47.8 \pm 2.76$ \\
A1B & $45.4 \pm 2.81$ & $47.1 \pm 2.39$ \\
A2 & $45.9 \pm 2.93$ & $45.5 \pm 3.07$ \\
B1 & $44.9 \pm 2.54$ & $46.6 \pm 1.97$ \\
\hline
\end{tabular}
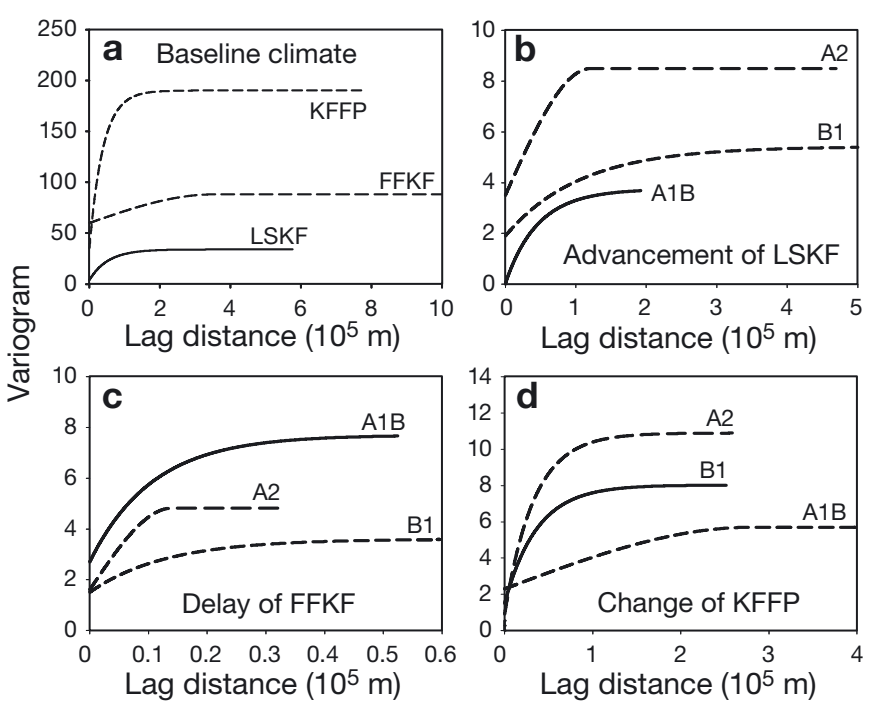

Fig. 4. Fitted variogram models for 60 weather stations in 1961-1990 for baseline climate and 2040-2069 for climate change scenarios: (a) killing frost indices under baseline climate, (b) Advance of last spring killing frost (LSKF), (c) delay in spring first killing frost (FFKF), and (d) change in killing frost free period (KFFP) under $\mathrm{A} 1 \mathrm{~B}, \mathrm{~A} 2$ and $\mathrm{B} 1$ climate change scenarios
1988) and the average harvest date is August 25, resulting in a growing season of approximately $110 \mathrm{~d}$ (Baier 1972). Therefore, killing frosts should not be a problem for wheat growth in the study region based on our derived data. However, because of temporal and spatial variability of killing frost, and also because of the prediction error of geostatistical techniques, there is no certainty that a killing frost will not occur during the indicated frost-free period (Fig. 5). For example, in 1968, $10 \%$ of the area sown with cereals in western Canada was destroyed, and grain yield was reduced by $50 \%$, as a result of widespread frost in early August (Hayter 1992). Therefore, caution should be used when using our results to adjust current agricultural practices.

\subsubsection{Climate change scenarios (2040-2069)}

We developed maps for the Canadian prairies showing the changes of killing frost indices under the 3 climate change scenarios (Fig. 6). Compared with the baseline climate, all climate change scenarios projected earlier LSKFs, later FFKFs and longer KFFPs. These changes were driven by the predicted temperature increase of the scenarios. A similar pattern of advance in LSKF was shown by scenarios A1B and A2: i.e. the advance decreased from the southwest towards the northeast. Results for Scenario B1 were broadly similar for Alberta and Manitoba but additionally showed a large advance in LSKF in central Saskatchewan.

All scenarios indicated that the greatest delay of FFKF occured in southwestern Saskatchewan. The

Table 5. Model parameters for variograms of killing frost indices (LSKF and FFKF: last spring and first fall killing frost, respectively; KFFP: killing frost free period) under baseline climate and for comparisons between baseline and alternative climate change scenarios. RMSE: root mean square error

\begin{tabular}{|lclcccrc|}
\hline $\begin{array}{l}\text { Agro-climate } \\
\text { indices }\end{array}$ & $\begin{array}{c}\text { Baseline and } \\
\text { Scenarios }\end{array}$ & \multicolumn{1}{c}{$\begin{array}{c}\text { Model } \\
\text { (direction) }\end{array}$} & $\begin{array}{c}\text { Nugget } \\
\left(c_{0}\right)\end{array}$ & $\begin{array}{c}\text { Sill } \\
\left(c_{0}+c_{s}\right)\end{array}$ & $\begin{array}{c}\text { Range } \\
(\alpha, \mathrm{m})\end{array}$ & $\begin{array}{c}\text { Nugget/sill } \\
(\%)\end{array}$ & $\begin{array}{c}\text { RMSE } \\
\text { LSKF }\end{array}$ \\
BFKF & Baseline & Exponential $\left(45^{\circ}\right)$ & 4 & 30 & 156973 & 11.8 & 2.11 \\
KFFP & Baseline & Spherical $\left(200^{\circ}\right)$ & 60 & 28 & 350000 & 68.2 & 10.21 \\
Advance of LSKF & Baseline & Exponential $\left(45^{\circ}\right)$ & 35 & 155 & 115130 & 20.6 & 4.67 \\
& A1B & Exponential $\left(45^{\circ}\right)$ & 0 & 3.7 & 135100 & 0.0 & 1.52 \\
& A2 & Spherical $\left(90^{\circ}\right)$ & 3.5 & 8.5 & 120750 & 41.2 & 1.53 \\
Delay in FFKF & B1 & Exponential $\left(190^{\circ}\right)$ & 1.9 & 5.4 & 320000 & 35.2 & 0.48 \\
& A1B & Exponential $\left(160^{\circ}\right)$ & 2.7 & 8.7 & 160000 & 35.13 & 7.87 \\
& A2 & Exponential $\left(50^{\circ}\right)$ & 1.6 & 4.8 & 70000 & 33.3 & 2.65 \\
Change in KFFP & B1 & Exponential $\left(45^{\circ}\right)$ & 1.5 & 3.6 & 194142 & 41.7 & 0.71 \\
& A1B & Exponential $\left(160^{\circ}\right)$ & 1.5 & 8 & 110000 & 18.8 & 2.76 \\
& A2 & Spherical $\left(0^{\circ}\right)$ & 0.9 & 10.9 & 100000 & 8.3 & 3.21 \\
& B1 & Spherical $\left(160^{\circ}\right)$ & 2.3 & 5.7 & 280000 & 40.4 & 0.44 \\
\hline
\end{tabular}


Table 6. Estimation errors of ordinary kriging for killing frost indices under baseline climate and in comparisons between baseline and alternative climate change scenarios. RMSSE: root mean squared standardized error; LSKF and FFKF: last spring and first fall killing frost, respectively; KFFP: killing frost free period

\begin{tabular}{|lccc|}
\hline Indices & $\begin{array}{c}\text { Baseline and } \\
\text { scenarios }\end{array}$ & $\begin{array}{c}\text { RMSE } \\
\text { (d) }\end{array}$ & RMSSE \\
\hline LSKF & Baseline & 5.38 & 0.92 \\
FFKF & Baseline & 9.07 & 0.99 \\
KFFP & Baseline & 14.17 & 1.01 \\
Advance of LSKF & A1B & 1.48 & 0.77 \\
& A2 & 2.17 & 0.72 \\
& B1 & 1.81 & 0.86 \\
Delay in FFKF & A1B & 2.23 & 0.79 \\
& A2 & 2.18 & 0.95 \\
Change in KFFP & B1 & 1.90 & 1.00 \\
& A1B & 2.08 & 0.71 \\
& A2 & 2.10 & 0.62 \\
& B1 & 1.84 & 0.85 \\
\hline
\end{tabular}

pattern of delayed FFKF elsewhere was not consistent among scenarios. The extent of delay shown in our findings is similar to the estimate by Rochette et al. (2004) that the first fall frost $\left(-2^{\circ} \mathrm{C}\right)$ will be delayed by $16 \mathrm{~d}$ in southern Ontario by 2040-2069.

For all scenarios, southwestern Saskatchewan had the greatest increase in KFFP compared to the rest of the prairies. Generally, the magnitude of the increase in KFFP increased from north to south in Alberta and Saskatchewan. Overall trends were similar in scenarios A1B and A2. In Manitoba, the KFFP increased more in the east than the west for scenarios A2 and
B1. Generally, comparing across the prairies as a whole, the median increase in KFFP was 18-20, 29-30 and $20-21 \mathrm{~d}$ for scenarios $\mathrm{A} 1 \mathrm{~B}, \mathrm{~A} 2$ and $\mathrm{B} 1$, respectively. Thus the increases in scenarios $\mathrm{A} 1 \mathrm{~B}$ and $\mathrm{B} 1$ were similar and less than in scenario A2. This reflects the higher projected temperature increase in scenario A2.

Agricultural impact studies have shown that potential climatic changes could lead to changes in agronomic practices (Alexandrov \& Hoogenboom 2000, Burton \& Lim 2005, IPCC 2000). With earlier LSKF, logically, seeding dates should be adjusted earlier, although soil temperature and moisture also need to be considered. Likewise, the predicted longer growing season due to climate change would enable a production shift to cultivars and crop types that are not currently suitable under the current KFFP.

Short KFFP is important in defining the current northern frontier of crop production on the Canadian prairies. Increases in KFFP along this frontier varied between scenarios but averaged at least $14 \mathrm{~d}$. Therefore, the results indicate a potential for a northerly expansion of the agriculture region, although most of the lands to the north of the current frontier will remain only marginally suitable for farming because of poor soil conditions. The results from this study also provide inputs for crop breeding programs by identifying the likely future growing conditions to which future cultivars will need to be adapted. The information can also be used to help producers adjust cropping practices to take advantage of longer growing seasons. For example, a longer growing season may be more favorable to other crops not currently widely grown such as corn and soybean (Bootsma et al. 2005).
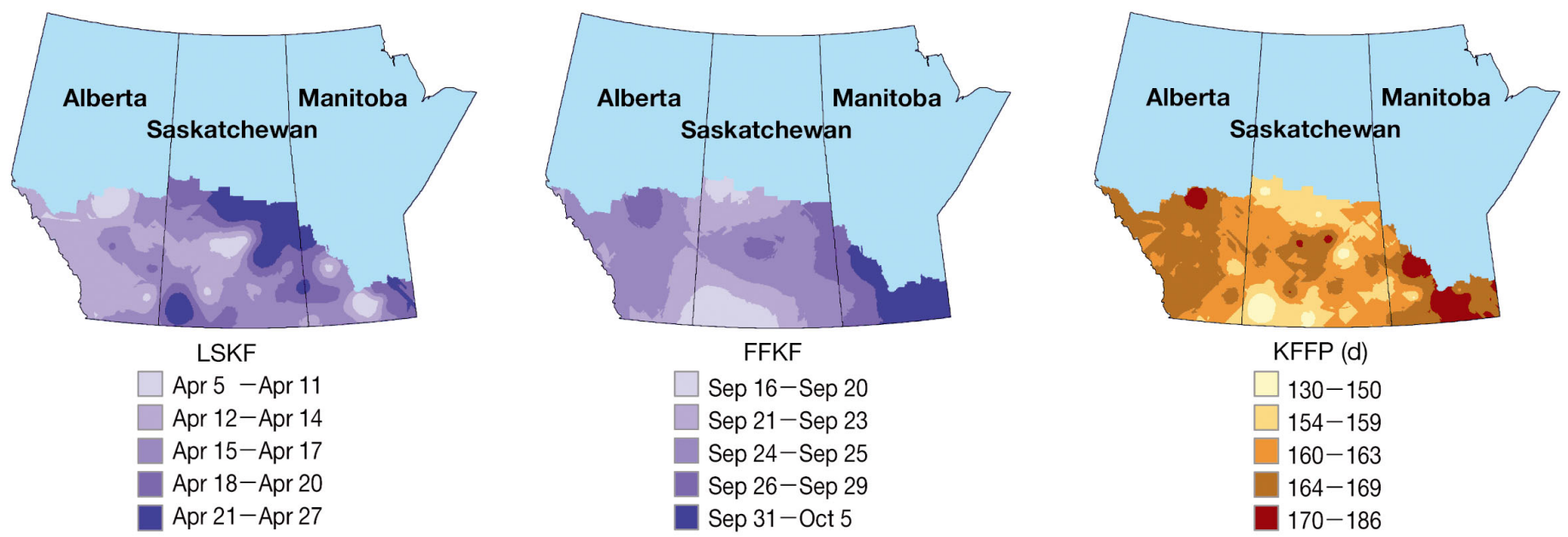

Fig. 5. Spatial distribution of killing frost indices under baseline climate for 1961-1990, based on data from 60 weather stations (LSKF and FFKF: last spring and first fall killing frost, respectively; KFFP: killing frost free period) 

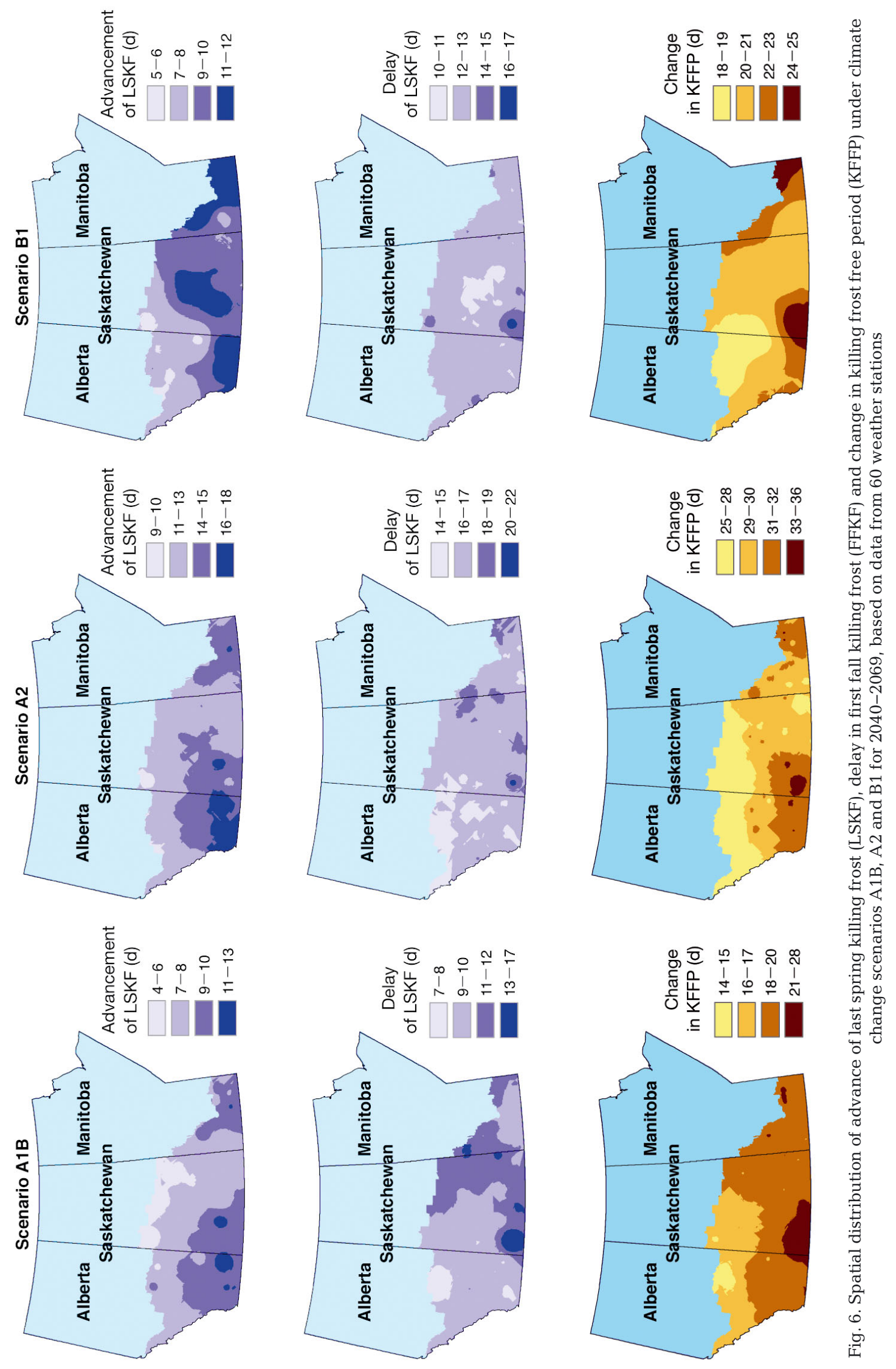


\section{CONCLUSIONS}

The climatic change scenarios on the Canadian prairies in 2040-2069, projected by CGCM3, were used to derive useful information about changes of killing frost indices in agricultural regions on the Canadian prairies under alternative climate change scenarios. Killing frosts are an important constraint to crop production in this region and the rising temperatures are predicted to have significant effects on LSKF, FSKF, and KFFP. LSKF is expected to occur earlier while FFKF is expected to be later over the entire region. As a result, KFFP is anticipated to become longer. However, the changes are projected to be non-uniformly distributed across the region.

Instead of directly using killing frost occurrence deduced from climate change scenarios to represent a large grid area, geostatistic techniques were applied to up-scale the results from weather stations to the whole agricultural region of the Canadian prairies. The results indicate that some areas, such as southwestern Alberta and eastern Manitoba will experience a greater advance of LSKF than other areas. Assuming precipitation patterns do not change, advancing seeding dates in these areas will help crops avoid stress from late summer droughts by allowing a larger portion of grain filling to occur earlier in summer. In areas with the greatest increase in KFFP, later maturing cultivars may be selected to take advantage of the projected longer growing season. However, because spatial interpolation is not an error free technique, these data should be used with caution as the basis for decision making.

Acknowledgements. This study was funded by Agriculture and Agri-Food Canada (Abase Project \#96). We gratefully acknowledge support for this research from the Visiting Fellowships in Canadian Government Laboratories Program, managed by the Natural Science and Engineering Research Council of Canada. We also thank Beaubier Aidan for her constructive comments. (O) Inter-Research and @ Her Majesty the Queen in the Right of Canada, as represented by the Minister of Agriculture and Agri-Food Canada 2012.

\section{LITERATURE CITED}

Alexandrov VA, Hoogenboom G (2000) Vulnerability and adaptation assessments of agricultural crops under climate change in the Southeastern USA. Theor Appl Climatol 67:45-63

- Baier W (1972) An agroclimatic probability study of the economics of fallow-seeded and continuous spring wheat in southern Saskatchewan. Agric Meteorol 9:305-321

Barrow EM, Hulme M (1996) Changing probabilities of daily temperature extremes in the UK related to future global warming and changes in climate variability. Clim Res 6 : 21-31

> Bootsma A, De Jong R (1988) Estimates of seeding dates of spring wheat on the Canadian Prairies from climate data. Can J Plant Sci 68:513-517

Bootsma A, Gameda S, McKenney DW (2005) Impacts of potential climate change on selected agro-climatic indices in Atlantic Canada. Can J Soil Sci 85:329-343

Burton I, Lim B (2005) Achieving adequate adaptation in agriculture. Clim Change 70:191-200

Canadian Climate Change Scenarios Network (CCCSN) (2012) Accessed 25 April. www.ec.gc.ca/sc-cs/default. asp?lang=En\&n=FE6B6E6B-1

Charron JB, Breton G, Danyluk J, Muzac I, Ibrahim RK, Sarhan F (2002) Molecular and biochemical characterization of a cold-regulated phosphoethanolamine N-methyltransferase from wheat. Plant Physiol 129: 363-373

Cohen S, Wheaton EE, Masterton J (1992) Impacts of climatic change scenarios in the prairie provinces: a case study from Canada. Canadian Climate Center, Downsview

> Conly FM, van der Kamp G (2001) Monitoring the hydrology of Canadian prairie wetlands to detect the effects of climate change and land use changes. Environ Monit Assess 67:195-215

Cutforth HW, O'Brien EG, Tuchelt J, Rickwood R (2004) Long-term changes in the frost-free season on the Canadian prairies. Can J Plant Sci 84:1085-1091

Deutsch CV, Journel AG (1992) GSLIB — Geostatistical software library and user's guide. Oxford University Press, New York

Dexter JE, Martin DG, Preston KR, Tipples KH, MacGregor AW (1985) Effect of frost damage on the milling and baking quality of red spring wheat. Cereal Chem 62:75-80

Environment Canada (1993) Canadian climate normals. Canadian Climate Program, Ottawa

Esbensen KH, Friis-Petersen HH, Petersen L, Holm-Nielsen JB, Mortensen PP (2007) Representative process sampling - in practice: variographic analysis and estimation of total sampling errors (TSE). Chemometr Intell Lab 88: 41-59

> Fuller MP, Fuller AM, Kaniouras S, Christopher J, Fredericks T (2007) The freezing characteristics of wheat at ear emergence. Eur J Agron 26:435-441

> Ganeshan S, Vitamvas P, Fowler DB, Chibbar RN (2008) Quantitative expression analysis of selected COR genes reveals their differential expression in leaf and crown tissues of wheat (Triticum aestivum L.) during an extended low temperature acclimation regimen. J Exp Bot 59: 2393-2402

> Geerts S, Raes D, Garcia M, Del Castillo C, Buytaert W (2006) Agro-climatic suitability mapping for crop production in the Bolivian Altiplano: a case study for quinoa. Agric For Meteorol 139:399-412

Goovaerts P (1997) Geostatistics for natural resources evaluation. Oxford University Press, New York, NY

Goovaerts P (1999) Impact of the simulation algorithm, magnitude of ergodic fluctuations and number of realizations on the spaces of uncertainty of flow properties. Stoch Env Res Risk A 13:161-182

> Gulick PJ, Drouin S, Yu Z, Danyluk J, Poisson G, Monroy AF, Sarhan F (2005) Transcriptome comparison of winter and spring wheat responding to low temperature. Genome 48:913-923

Hayter R (1992) Frost hazard in north-east central Alberta. 
In: Mohammad N (ed) New dimensions in agricultural geography, Vol 2. The ecology of agricultural systems. Concept publishing, New Delhi, p 213-234

Herrington R, Johnson R, Hunter F (1997) Responding to global climate change in the Canadian prairies. Canada country study: climate impacts and adaptation, Vol. 3. Environment Canada, Ottawa

- Hijmans RJ, Condori B, Carrillo R, Kropff MJ (2003) A quantitative and constraint-specific method to assess the potential impact of new agricultural technology: the case of frost resistant potato for the Altiplano (Peru and Bolivia). Agric Syst 76:895-911

Holdaway MR (1996) Spatial modeling and interpolation of monthly temperature using kriging. Clim Res 6:215-226

IPCC (2000) Special report on emissions scenarios. Contribution of Working Group III of the Intergovernmental Panel on Climate Change. Cambridge University Press, Cambridge

Isaaks EH, Srivastava RM (1989) An introduction to applied geostatistics. Oxford University Press, New York, NY

Johnston K, Ver Hoef JM, Krisvoruchko K, Lucus N (2001) Using ArcGIS ${ }^{\mathrm{TM}}$ Geostatistical Analyst-GIS by ESRI ${ }^{\mathrm{TM}}$. ESRI. Redlands, CA

Jones JW, Hoogenboom G, Porter CH, Boote KJ and others (2003) The DSSAT cropping system model. Eur J Agron 18:235-265

Kim SJ, Flato GM, Boer GJ, McFarlane NA (2002) A coupled climate model simulation of the Last Glacial Maximum. I. Transient multi-decadal response. Clim Dyn 19:515-537

Kim SJ, Flato GM, Boer GJ (2003) A coupled climate model simulation on the Last Glacial Maximum. II. Approach to equilibrium. Clim Dyn 20:636-661

Longley RW (1967) The frost free period in Alberta. Can J Plant Sci 47:239-249

Macdowall FDH (1974) Growth kinetics of Marquis wheat. VI. Genetic dependence and winter hardening. Can J Bot 52:151-157

McGinn SM, Touré A, Akinremi OO, Major DJ, Barr AG (1999) Agroclimatic and crop response to climate change in Alberta. Canada. Outlook Agric 28:19-28

Mkhabela MS, Bullock P, Raj S, Wang S, Yang Y (2011) Crop yield forecasting on the Canadian Prairies using MODIS NDVI data. Agric For Meteorol 151:385-393

Nadler AJ (2007) An agro-climatic risk assessment of crop production on the Canadian Prairies. MS thesis, University of Manitoba, Winnipeg. hdl.handle.net/1993/2829

Parry M (1990) Climate change and world agriculture. Earthscan, London

Preston KR, Kilburn RH, Morgan BC, Babb JC (1991) Effects of frost and immaturity on the quality of a Canadian hard red spring wheat. Cereal Chem 68:133-138

Qian B, Gameda S, Hayhoe H, De Jong R, Bootsma A (2004) Comparison of LARS-WG and AAFC-WG stochastic

Editorial responsibility: Oliver Frauenfeld,

College Station, Texas, USA weather generators for diverse Canadian climates. Clim Res 26:175-191

- Qian B, Hayhoe H, Gameda S (2005) Evaluation of the stochastic weather generators LARS-WG and AAFC-WG for climate change impact studies. Clim Res 29:3-21

Qian B, Gameda S, De Jong R, Falloon P, Gornall J (2010a) Comparing scenarios of Canadian daily climate extremes derived using a weather generator. Clim Res 41: 131-149

> Qian B, Zhang X, Chen K, Feng Y, O'Brien T (2010b) Observed long-term trends for agroclimatic conditions in Canada. J Appl Meteorol Climatol 49:604-618

Qian B, De Jong R, Yang J, Wang H, Gameda S (2011) Comparing simulated crop yields with observed and synthetic weather data. Agric For Meteorol 151:1781-1791

Qian B, Gameda S, Zhang X, De Jong R (2012) Changing growing season observed in Canada. Clim Change 112: 339-353

Quiring SM, Papakryiakou TN (2003) An evaluation of agricultural drought indices for the Canadian prairies. Agric For Meteorol 118:49-62

> Raddatz RL (1998) Anthropogenic vegetation transformation and the potential for deep convection on the Canadian prairies. Can J Soil Sci 78:657-666

Reinheimer J (2010) The genetic improvement of wheat and barley for reproductive frost tolerance. PhD thesis, University of Adelaide

> Rochette P, Bélanger G, Castonguay Y, Bootsma A, Mongrain D (2004) Climate change and winter damage to fruit trees in eastern Canada. Can J Plant Sci 84:1113-1125

SAS Institute (1999) SAS procedures guide. Version 8. SAS Institute, Cary, NC

Sharratt BS, Knight CW, Wooding F (2003) Climatic impact on small grain production in the subarctic region of the United States. Arctic 56:219-226

Shroyer JP, Mikesell ME, Paulsen GM (1995) Spring freeze injury to Kansas wheat. Cooperative Extension Service, Kansas State University, Manhattan, KS

Single WV, Marcellos H (1974) Studies on frost injury to wheat. IV. Freezing of ears after emergence from the leaf sheath. Aust J Agric Res 25:679-686

Statistics Canada (2011) Field crop reporting series. (March intentions of principal field crop areas). Catalogue no. 22-002-x. Statistics Canada, Ottawa

Wang H, Cutforth H, McCaig T, McLeod G and others (2009) Predicting the time to $50 \%$ seedling emergence in wheat using a Beta model. Wageningen J Life Sci 57:65-71

> Whaley JM, Kirby EJM, Spink JH, Foulkes MJ, Sparkes DL (2004) Frost damage to winter wheat in the UK: the effect of plant population density. Eur J Agron 21:105-115

- Woodcock CE, Strahler AH, Jupp DLB (1988) The use of variograms in remote sensing. I. Scene models and simulated images. Remote Sens Environ 25:323-348

Submitted: September 1, 2011; Accepted: June 4, 2012

Proofs received from author(s): September 25, 2012 